\title{
Supply Chain Finance: Historical Foundations, Current Research, Future Developments
}

Federico Caniato, School of Management, Politecnico di Milano*

Michael Henke, TU Dortmund and Fraunhofer IML

\author{
George A. Zsidisin, School of Business, Virginia Commonwealth University \\ * Corresponding author: federico.caniato@polimi.it
}

\begin{abstract}
It is widely agreed that supply chains encompass and integrate material, information, and financial flows across organizations. There is a robust history and continually expanding research agenda investigating supply chain management practice and theory associated with material and information flows and processes. However, the management of financial flows from a supply chain perspective and in combination with the other flows, usually referred to as supply chain finance (SCF), has been under-investigated. Our understanding of SCF approaches and solutions in purchasing and supply management (PSM) is only starting to form. The purpose of this editorial is to provide some grounding of initial studies and concepts of SCF, illustrate new and emerging thought in this discourse with articles published in this special issue, and speculate how the SCF domain may evolve in theory and practice with the advent of new digital technologies and big data analytics.
\end{abstract}

\section{Full reference:}

Caniato, F., Henke, M., \& Zsidisin, G. A. (2019). "Supply Chain Finance: Historical Foundations, Current Research, Future Developments". Journal of Purchasing and Supply Management, Vol. 25, No. 2, pp. 99-104. DOI: 10.1016/j.pursup.2019.02.002

Author's post-print released with a Creative Commons Attribution Non-Commercial No Derivatives License 


\section{Historical Foundations of Supply Chain Finance}

Supply chain management (SCM) has long been defined and conceptualized as structuring, coordinating and integrating three flows along supply chains - material, information and financial. Although both theory and practice have mostly focused on studying and optimizing material and information flows, there has been scant attention towards understanding financial flows (Wuttke et al. 2013; Pfohl and Gomm 2009). Until the global financial crisis of 20082009, there was little imperative for companies to address liquidity problems or actively manage their supply chain's working capital due to highly liquid capital markets. During the financial crisis, the credit crunch affected in particular small and medium enterprises (SMEs), leading many suppliers to bankruptcy and threatening the stability of established supply chains worldwide (Hofmann and Belin 2011). Companies began to realize the benefits of managing financial flows in collaboration with supply chain partners and financial institutions and started seeking advanced methods to strengthen their financial supply chains (de Boer et al. 2015). Such methods were emerging in the literature utilizing the newly formed areas of inquiry labelled financial supply chain management (FSCM) and supply chain finance (SCF). Although different definitions of the two terms exist, today they are used interchangeably, with SCF being more prevalent (Gelsomino et al., 2016).

In this Special Issue we adopt the broad perspective of SCF provided by Gelsomino et al. (2016 p. 348): "SCF aims to optimise financial flows at an inter-organisational level (Hofmann, 2005) through solutions implemented by financial institutions (Camerinelli, 2009) or technology providers (Lamoureux and Evans, 2011). The ultimate objective is to align financial flows with product and information flows within the supply chain, improving cashflow management from a supply chain perspective."

Published research in SCF has started providing insight to a wide range of tools and management practices for effectively planning and controlling financial flows among supply chain parties. Even after the crisis, the importance of SCF remains undiminished. This is due, 
in part, to the development of conservative credit models and increased regulatory capital requirements for banks, resulting in many small and medium companies lacking access to credit (Serrano and Lekkakos 2016).

SCF offers a portfolio of financial, technological and managerial instruments to optimize working capital management and unlock liquidity tied up in supply chain processes and transactions (BAFT et al. 2016; Caniato et al., 2016). Moreover, SCF practices can be utilized to solve conflicting financial interests between suppliers and buyers and thus strengthen their relationships. Whereas buyers often prefer to extend payments terms, suppliers instead usually desire to accelerate the payment for sold goods or services. This often results in stronger firms (e.g. large buyers) imposing longer payment terms to the weaker ones (e.g. smaller suppliers). However weaker firms are usually less able to gather financial resources to support higher levels of working capital, as well as encounter higher financing costs. So, in the long run this creates inefficiencies and risks in the supply chain, which affect also the stronger firms. SCF can create win-win situations for both parties, for example by providing financing solutions allowing buyers to delay payment while suppliers are getting paid faster at lower costs by leveraging the strong credit rating of the buyer. Other solutions aim to reduce the amount of working capital for both buyer and supplier, thus optimizing the supply chain's overarching financial performance (Hofmann et al. 2018). Several SCF solutions are available and described in the literature (e.g. Caniato et al., 2016). While the initial SCF solutions target either dyadic buyer-supplier relationships, or one-to-many relationships involving a large buyer and its supply base, more recently multi-tier solutions have been introduced, involving companies in multiple tiers of the supply chain, usually driven by a focal company.

Initially, SCF services were introduced by large banks. However, with the growing demand for SCF, new and innovative financing models evolved and bank-independent platform providers (financial service providers and later "fintechs") entered the market (Caniato et al. 2016). As a result, the current SCF landscape is highly fragmented and companies often need 
to engage in multiple, different SCF platforms operated by banks and financial service providers, requiring a multiplication of efforts to join and manage these platforms (Nienhuis et al. 2013). While in the beginning SCF was oriented mainly toward optimizing working capital and liquidity management, today's solutions aim also at collaboration and efficiency gains.

\section{Supply Chain Finance in Purchasing and Supply Management}

To date the literature on SCF is still underdeveloped. Recent literature reviews, such as Gelsomino et al. (2016) and Xu et al. (2018), show SCF has been addressed either in the finance literature, focusing mostly on third party financial institutions providing short-term financing solutions for accounts payables and receivables, or in the supply chain literature, considering solutions oriented to working capital optimisation in terms of accounts payable, receivable, and inventories, with or without the involvement of financial institutions. Further, most research contributions are conceptual or utilize mathematical models often lacking empirical evidence (e.g. Wuttke et al., 2016; Serrano and Lekkakos, 2016). These studies focus mainly on understanding SCF solutions from the buyer's perspective, often neglecting the other firms (suppliers and financial institutions) involved.

There is a need for developing knowledge in SCF, harmonizing contributions of a more financial nature with those coming from a more supply chain orientation. For example, SCF so far has been relatively neglected in the purchasing and supply management (PSM) literature. PSM serves a critical role in SCF due to its strategic approach to the management of the supply base, not only in terms of financial flows optimisation, but also from relationship improvement and risk management.

One of the most widely diffused SCF solutions is reverse factoring (Wuttke et al., 2013), which is a financial agreement where a financial institution purchases accounts receivable from selected, information-transparent, high-quality buyers, with a credit risk which is lower than the one of their more risky suppliers (i.e. suppliers that are financially weaker and therefore 
have a higher risk of default and consequently a higher financing cost). This also gives the supplier access to short-term credit at a lower cost. Such solutions are typically initiated by large buyers who are interested in supporting their supply base, giving them access to credit at lower costs, and also reducing the supply risk for the buyer.

Research on SCF from a PSM perspective needs to be further developed, which prompted the call for papers and ultimately resulted in this special issue. The idea was to gather empirical evidence that might prove useful for testing existing models and hypotheses, address the more innovative SCF schemes, improve understanding of the adoption level of particular techniques, as well as assess the state of development for different solutions.

The plurality of solutions shaping the SCF landscape means that research should move towards holistic processes in choosing the best SCF solution for a supply chain, considering its financial performance and its contextual variables (e.g. structure, bargaining power). In line with the definition of SCF set out above, and in order to address the limitations of existing research, in this special issue a broad perspective of SCF has been adopted. Many of the articles in this special issue consider not only different SCF solutions, but also more general issues such as financial risk management and credit ratings, the perspective of the various actors involved, and the distribution of costs and benefits among them.

\section{Current Research: Contributions to the Special Issue on Supply Chain Finance}

All of the eight selected research articles in this special issue help form and advance our understanding of the developing domain of SCF. These manuscripts provide guidance to a more complete perspective of SCF from varying theoretical (resource dependency theory, network theory, social exchange theory, transaction cost economics, principal agent theory, contingency theory, game theory, stakeholder theory, business ecosystem), methodological (real options valuation, econometric model testing, case studies, non-linear programming, literature review, focus groups, optimization models), topical (commodity price volatility, supply networks, 
supply chain financing scheme selection, credit rating, payment terms, supply chain collaboration), and industry (i.e. automotive, food, retail, fast moving consumer goods) perspectives. Each of these contributions is summarized in Table 1.

[Insert Table 1 About Here]

The first manuscript in this special issue, "Toward a Supply Chain Finance (SCF) Ecosystem - Proposing a Framework and Agenda for Future Research," presents the results of a systematic review of the SCF literature and proposes a comprehensive framework to support the investigation of the overall business ecosystem in which SCF is embedded. The framework consists of 8 dimensions: supply chain collaboration, organization, financial, technology, market and regulation, product, stakeholder perspective and life-cycle. A significant contribution is a proposal for a research agenda to investigate the SCF ecosystem.

The next article in the special issue, "Supply Chain Finance: A Supply Chain Oriented Perspective to Mitigate Commodity Price Risk and Volatility," examines how supply chain flexibility can be utilized to reduce the detrimental financial effects of unfavourable commodity price movements. This research utilizes a real options valuation (ROV) simulation to examine how investing in supply chain flexibility capabilities, specifically in terms of switching suppliers and substituting commodities, can be analysed and developed for mitigating commodity price risk. The findings suggest that firms can utilize supply chain flexibility approaches extending beyond the traditional use of financial hedging instruments to mitigate this form of financial risk, and how ROV models can be developed for understanding to how best invest their resources in creating supply chain flexibility capabilities, and their respective financial effects. 
This is followed by "Broadening the Perspective of Supply Chain Finance: The Performance Impacts of Network Power and Cohesion," which focuses on how network structures can influence firm financial success. Network structure in terms of network power and cohesion are examined from secondary data in how they influence financial performance in terms of the cash conversion cycle (CCC), earnings before interest, taxes, depreciation, and amortization (EBITDA), and return on assets (ROA). Findings from this study contribute to understanding of supply chain finance by discerning how developments in supply network structures influences earnings and financial performance in different ways.

"Towards a Framework of Supply Chain Finance for the Supply Side," provides a contingency approach for best selecting supply chain financing approaches. This research utilizes data from eight triadic buyer-supplier-financial service provider relationships, and offers a novel framework for supply chain professionals selecting financing alternatives based on the time of financing (pre or post shipment) and source of funding (external or internal). This manuscript contributes to the special issue theme by providing a strategy for implementing various supply chain financing schemes, including approved payables financing, dynamic discounting, inventory financing, purchase order financing, advanced hedging, and natural financing techniques.

Next, "Optimizing the Credit Term Decisions in Supply Chain Finance," studies supplier credit term decisions with relation to production, inventory, and order quantity decisions. Grounded in game theory and utilizing a novel optimization approach named the bilevel credit term optimization problem with real-world data, the findings from the study provide PSM professionals an approach for making optimal dynamic credit term decisions.

"Supply Chain Finance Schemes in the Procurement of Agricultural Products" studies contracts in the procurement of agricultural raw materials by food and beverage companies. The paper compares three alternatives which imply a different level of supply chain coordination and financial support to the suppliers and risk for the buyer. The model considers 
a three-stage supply chain and different funding costs to identify under which conditions each alternative is preferable for the buyer, while considering also the impact for suppliers. The paper includes an application of the model to the real case of Heineken's barley-malt supply chain.

The next article in this special issue, "An Optimisation Strategy for Concurrent Supply Chain Finance Schemes" also addresses the problem of selecting the most suitable SCF scheme to be adopted with each supplier. The paper considers reverse factoring, inventory financing and dynamic discounting, and proposes an optimization model to allocate each supplier to the scheme that maximizes the benefits for the buyer, according to the characteristics and needs of both customer and supplier, considering funding limits for each solution. The model is applied to the case of a large retailer and its suppliers.

The final article, "Supply Chain Finance: From Traditional to Supply Chain Credit Rating", addresses the problem of improving the accuracy of credit rating, in particular for smaller firms, by proposing an innovative supply chain credit rating, which combines traditional financial ratings performed by financial institutions with the operational ratings performed by customers. By means of focus groups and case studies with multiple actors representing the different stakeholders involved (buyers, suppliers, financial institutions and technology providers), the article highlights the benefits and challenges of supply chain credit ratings for each of them.

The eight articles included in this special issue provide a broad and rich addition to the SCF literature. They also open the way for developing future SCF research directions including real time information and data analytics.

\section{Future Developments: The Role of Real-Time Information and Data Analytics}

The articles in this special issue highlight the need to address the role of real time information, data analytics and digital technologies, which emerged as a particularly promising and relevant theme for both theory and practice. This is driven by the fact that there is a shift in 
technology occurring today that is significantly improving our ability to create greater organizational value through SCF. There is a prevalence of networks, smart devices, objects, machines and systems intelligently connecting people, things, processes and data.

These technologies facilitate continuously collecting, measuring and exchanging data in real time between organisations along the supply chain. The availability of real time data not only brings advantages for manufacturing but also for supply chain processes (Stich et al. 2015). Real-time information availability in combination with corresponding statistics, mathematics, econometrics, simulations, optimizations, and other techniques (Wang et al. 2016) allow faster reactions to changing conditions along the supply chain (Güller et al. 2015). The technological development and rising integration of real-time data in material, information and financial flows is a 'game changer'.

Managers will be expected to consider new sources of information such as social media platforms, public news, records of natural disasters, and consider politics, economic developments including currency fluctuations and numerous other factors in real-time to improve supply chain performance in terms of both effectiveness and efficiency, as well as allowing better risk management and improving sustainability (Choi et al., 2018; Dubey et al., 2018; Boone et al., 2019). Further, this information availability and interconnectivity will also enable more transparency and value in SCF. Several of these techniques and approaches, such as the use of multiple sources of data to improve credit rating and information sharing along the supply chain to select the most suitable SCF scheme, are discussed in articles in this special issue, such as those by Bals, Gelsomino et al., Van Bergen et al., and Moretto et al.

Big data analytics (BDA) is assuming a key role; big data are usually defined by the 5Vs (volume, velocity, variety, veracity and value) (Fosso Wamba et al., 2015) and require specific tools and methods to be analysed and exploited (Sivarajah et al., 2017). With the help of BDA, information is converted into business intelligence, which leads to a better understanding of events from the past but also capabilities to predict future events (Sanders 2014). Moreover, 
BDA aims to provide a more accurate and reliable decision-making basis for further actions. BDA techniques are classified into descriptive, predictive and prescriptive analytics (Evans and Lindner, 2012).

Descriptive analytics provide a static overview of a current state of a business situation based on data collected in the past. The analysis provides answers to questions such as "What happened?" and "What is happening?" (Wang et al. 2016). Several papers in this special issue, such as Gelsomino et al. and Van Bergen et al., use descriptive analytics as a starting point to analyse SCF issues and propose innovative solutions, although they do not limit themselves to a static description of the context, instead proposing a more dynamic and future-looking approach.

Predictive analytics provide estimations about the future state using business forecasting and simulation to answer questions of "what will happen?" and "why will it happen?" (Delen and Demirkan, 2013). These estimates can be made with regard to SCF, including understanding flows, valuations and optimal contracting schemes, sometimes with third parties. For example, in this special issue, the paper by Moretto et al. discusses the potential of combining diverse information flows, both financial and operational, to provide a better assessment of credit rating for SMEs, i.e. a better prediction of their probability of default, thus enabling improved access to funding for those firms with a lower risk. Another example is the paper by Pellegrino et al, which considers the use of real options to assess the impact of the development of supply chain flexibility capabilities to mitigate the effects of commodity price volatility.

Prescriptive analytics is used to recommend a course of actions for a given predicted future by using simulation and optimization and addresses questions such as "what shall we do?" and "why shall we do it?" (Evans and Lindner, 2012). This form of analytics can likewise be applied with SCF. For example, as shown in Gelsomino et al. and Van Bergen et al., analytics can support the choice of the most appropriate solution or scheme for each specific case, as well 
as the optimal combination of multiple ones to maximize the benefits for the parties involved. Another example is provided by Li et al., who propose an optimization model for dynamically determining supplier credit terms.

BDA is expected to have a major impact on SCF, in multiple ways, and to open the way to new and relevant applications. However, there are also other major innovative digital technologies that are impacting supply chains in general and SCF in particular: internet of things (IoT), blockchain and smart contracts.

IoT is defined as the use of distributed sensors to gather real time information on goods' position, status and condition and to share it on the Internet (Parry et al., 2016, Papert et al., 2016). Having real-time visibility on goods in the supply chain enables advanced SCF solutions, such as inventory finance and purchase order finance.

Unlike conventional enterprise solutions, where the relevant data is stored in a centralized and isolated manner, blockchain is a distributed ledger technology which has the ability to securely digitize many current operations and to share all transaction information between network parties (Yoo, 2017). Blockchain inherently provides several key technological advantages to users from its structural architecture, including durability, transparency, immutability and process integrity (Abeyratne and Monfared 2016, Apte and Petrovsky 2016). Due to the elimination of the need for a central authority, blockchain has the potential to also serve as a disruptive technology for SCF and enable new solutions, such as blockchain-based letter of credit, bill of lading, factoring and reverse factoring (Hofmann et al., 2018). With the potential to serve as an appropriate transaction layer for information, blockchain is able to build a digital backbone with IoT and increase visibility into the structure of extended supply chains (Biswas and Sen, 2016; Babich and Hilary, 2018). Blockchain can also help to leverage the full potential of SCF through the application of approaches such as reverse factoring along the whole upstream supply chain. In this context, the promising idea of smart contracts has emerged in recent years. A smart contract can be defined as "a computerized transaction protocol that 
executes the terms of a contract" (Szabo, 1994). In smart contracts, the contractual agreements are converted into computer code, stored in the blockchain, and executed automatically by the code (Christidis and Devetsikiotis, 2016). Also, smart contracts enable significant opportunities for SCF, for example by providing the possibility to automate financial transactions, such as payment, when the corresponding physical transaction occurs.

The combination of IoT, blockchain and smart contracts opens up a whole range of innovative possibilities for SCF, which are currently under development and testing. For example, IoT sensors can monitor the position and status of goods along the supply chain; such information can be shared on the blockchain with interested parties, and smart contracts can trigger automated financial flows when the corresponding event takes place (Hofmann et al 2018). This is not only a benefit in terms of speed and efficiency of transactions, but the technology enables solutions that are currently very difficult to implement due to the lack of visibility and trust, as in the case of inventory finance.

While digital technologies and data analytics enable innovative applications and offer the potential for new and better supply chain finance solutions, they also enable the involvement of new actors, such as logistic service providers, information technology providers, fintechs, alternative investors, and trade insurances. This in turn opens further new interesting research opportunities, since the landscape of participants becomes richer and more complex, requiring a better understanding of costs and benefits, as well as drivers and barriers.

\section{Conclusion}

In this special issue on Supply Chain Finance we have collected a rich set of diverse contributions, showing how this field is growing and developing, but also opening up new directions and suggestions for further research. The comprehensive literature review by Bals provides a broad perspective on the SCF ecosystem and suggests eight major directions for future research, namely supply chain collaboration, organization, financial, technology, market 
$\&$ regulation, product, stakeholder perspective and life-cycle. Each of them addresses relevant and still under-investigated issues, which deserve dedicated efforts to contribute to both research and practice. The other articles included in this special issue have tackled some of these issues, such as the selection of different solutions (Pellegrino et al., Gelsomino et al.), the perspective of multiple stakeholders (Martin and Hofmann, Moretto et al.), and benefit sharing (Li et al., Van Bergen et al.). However, there is still ample need and space for further research, both on these and other directions, as suggested also in the articles of this special issue. We believe research in SCF needs to develop in various directions:

- the combination of multiple (and new) solutions, addressing not only receivables and payables, but also inventories and purchase orders, and even fixed assets;

- the role and interaction of multiple (and new) actors, including multiple tiers in the supply chain, traditional and innovative financial providers, technology and information providers, logistic service providers, and trade insurance companies;

- the role of multiple (and new) technologies, such as BDA, IoT, blockchain and smart contracts, to enable new solutions and overcome the limitations of current ones;

- the use of multiple (and new) theoretical lenses, to better address the challenges and implications of SCF research, to analyse and explain the management of relevant tradeoffs, such as the fundamental one between effectiveness and efficiency;

- the identification of multiple (and new) performance dimensions, going beyond pure financial indicators, to consider for example strategic impact, risk management, and sustainability improvement;

- the analysis of multiple (and new) costs and benefits, for the various actors involved, addressing the fundamental issue of optimizing performance for the entire supply chain, and not only for a single actor at the expenses of others, and consequently finding the proper cost and benefit sharing mechanisms. 
In many ways SCF is the "new frontier" of research in supply chain management. With the emergence of new technologies and processes, we foresee how managing supply chain financial flows, in conjunction with material and information flows, can provide greater efficiencies and value for firms today and in the future.

\section{References}

Abeyratne, S.A., Monfared, R.P. (2016) Blockchain ready manufacturing supply chain using distributed ledger. International Journal of Research in Engineering and Technology, 5(9), 110 .

Apte, S. \& Petrovsky, N. (2016) Will blockchain technology revolutionize excipient supply chain management? Journal of Excipients and Food Chemicals, 7(3), 76-78.

Babich, V., Hilary, G. (2018) Distributed Ledgers and Operations: What Operations Management Researchers Should Know About Blockchain Technology. Georgetown McDonough School of Business Research Paper No. 3131250.

BAFT; European Banking Association (EBA); Factors Chain International (FCI); International Chamber of Commerce (ICC); International Trade and Fortfaiting Association (IFTA) (2016) Standard definitions for techniques of supply chain finance. Available online at https://www.iccgermany.de/fileadmin/user_upload/Content/Banktechnik_und_praxis/Standard_Definitions_for_Techniques_of_Supply_Chain_Finance_Global_SCF_Foru m_2016.pdf, checked on 5/30/2018.

Biswas, S. and Sen, J. (2016). A Proposed Architecture for Big Data Driven Supply Chain Analytics. International Journal of Supply Chain Management, June.

Boone, T., Ganeshan, R., Jain, A., \& Sanders, N. R. (2018). Forecasting sales in the supply chain: Consumer analytics in the big data era. International Journal of Forecasting.

Camerinelli, E. (2009). Supply chain finance. Journal of Payments Strategy \& Systems, 3(2), 114-128.

Caniato, F., Gelsomino, L., Perego, A., Ronchi, S., (2016) Does finance solve the supply chain financing problem? Supply Chain Management: An International Journal, 21(5), 534-549.

Choi, T. M., Wallace, S. W., \& Wang, Y. (2018). Big data analytics in operations management. Production and Operations Management, 27(10), 1868-1883.

Christidis, K., \& Devetsikiotis, M. (2016). Blockchains and smart contracts for the internet of things. Ieee Access, 4, 2292-2303.

de Boer, R.; van Bergen, M.; Steeman, M. (2015): Supply Chain Finance, its Practical Relevance and Strategic Value. The Supply Chain Finance Essential Knowledge Series (2nd ed.). Zwolle, The Netherlands.

Delen, D. \& Demirkan, H., 2013. Data, infomation and analytics as services. Decision Support Systems, 55(1), pp.359-63. 
Dubey, R., Gunasekaran, A., Childe, S. J., Luo, Z., Wamba, S. F., Roubaud, D., \& Foropon, C. (2018). Examining the role of big data and predictive analytics on collaborative performance in context to sustainable consumption and production behaviour. Journal of Cleaner Production.

Evans, J. R., \& Lindner, C. H. (2012). Business analytics: the next frontier for decision sciences. Decision Line, 43(2), 4-6.

Fosso Wamba, S., Akter, S., Edwards, A., Chopin, G., \& Gnanzou, D. (2015). How 'big data'can make big impact: Findings from a systematic review and a longitudinal case study. International Journal of Production Economics, 165, 234-246.

Gelsomino, L.M., Mangiaracina, R., Perego, A., Tumino, A., (2016) Supply Chain Finance: a literature review. International Journal of Physical Distribution \& Logistics Management, 46, $1-19$.

Güller, M.; Koc, E.; Hegmanns, T.; Henke, M.; Noche, B. (2015) A simulation-based decision support framework for real-time supply chain risk management. International Journal of Advanced Logistics 4 (1), 17-26.

Hofmann, E. (2005). Supply chain finance: some conceptual insights. Beiträge Zu Beschaffung Und Logistik, 203-214.

Hofmann, E., Heines, R., \& Omran, Y. (2018). Foundational premises and value drivers of blockchain-driven supply chains: the trade finance experience. In Ellram, L., Bals, L., \& Tate, W. (Eds.). (2018). Supply Chain Finance: Risk Management, Resilience and Supplier Management. Kogan Page Publishers.

Hofmann, E.; Belin, O. (2011) Supply Chain Finance Solutions. Relevance - Propositions Market Value. Berlin, Heidelberg: Springer-Verlag (SpringerBriefs in Business).

Hofmann, E.; Strewe, U. M.; Bosia, N. (2018) Supply Chain Finance and Blockchain Technology. The Case of Reverse Securitisation. Cham: Springer International Publishing (SpringerBriefs in Finance).

Lamoureux, J. F., \& Evans, T. (2011). Supply chain finance: a new means to support the competitiveness and resilience of global value chains.

Nienhuis, J. J.; Corte, M.; Lycklama, D. (2013) Real-time financing: Extending e-invoicing to real-time SME financing. Journal of Payments Strategy \& Systems 7 (3), pp. 232-245.

Papert, M., Rimpler, P., \& Pflaum, A. (2016). Enhancing supply chain visibility in a pharmaceutical supply chain: Solutions based on automatic identification technology. International Journal of Physical Distribution \& Logistics Management, 46(9), 859-884.

Parry, G. C., Brax, S. A., Maull, R. S., \& Ng, I. C. (2016). Operationalising IoT for reverse supply: The development of use-visibility measures. Supply Chain Management: An International Journal, 21(2), 228-244.

Pfohl, H.-C.; Gomm, M. (2009) Supply chain finance. Optimizing financial flows in supply chains. Logistics Research 1 (3), 149-161.

Sanders, N. R. (2014) Big data driven supply chain management. A framework for implementing analytics and turning information into intelligence. Upper Saddle River, NJ: Pearson Education.

Schrauf, S. and Bertram, P. (2017) Industry 4.0: How digitization makes the supply chain more efficient, agile, and customer-focused. Price Waterhouse Coopers Strategy 
Serrano, A.; Lekkakos, S. D. (2016) Supply chain finance for small and medium sized enterprises. The case of reverse factoring. International Journal of Physical Distribution \& Logistics Management 46 (4), pp. 367-392.

Sivarajah, U., Kamal, M. M., Irani, Z., \& Weerakkody, V. (2017). Critical analysis of Big Data challenges and analytical methods. Journal of Business Research, 70, 263-286.

Stich, V.; Adema, J.; Blum, M.; Reschke, J. (2015) Supply Chain 4.0: Logistikdienstleister im Kontext der vierten industriellen Revolution. In: Peter H. Voß (Hg.): Logistik -- eine Industrie, die (sich) bewegt. Strategien und Lösungen entlang der Supply Chain 4.0. Wiesbaden: Springer Gabler, 63-76.

Szabo, N. (1994). Smart contracts. Virtual School.

Wang, G., Gunasekaran, A., Ngai, E.W.T., Papadopoulos, T. (2016) Big data analytics in logistics and supply chain management. Certain investigations for research and applications. International Journal of Production Economics 176, 98-110.

Wuttke, D. A.; Blome, C.; Henke, M. (2013): Focusing the financial flow of supply chains. An empirical investigation of financial supply chain management. International Journal of Production Economics 145 (2), 773-789.

Xu, X., Chen, X., Jia, F., Brown, S., Gong, Y., \& Xu, Y. (2018). Supply chain finance: A systematic literature review and bibliometric analysis. International Journal of Production Economics.

Yoo, S. (2017). Blockchain based financial case analysis and its implications. Asia Pacific Journal of Innovation and Entrepreneurship, 11(3), 312-321. 
Table 1. Summary of Special Issue Articles

\begin{tabular}{|c|c|c|c|c|c|}
\hline Author(s) & Title & Methodology & Theory adopted & Research contribution & Managerial implications \\
\hline Cristof Bals & $\begin{array}{l}\text { Toward a Supply Chain } \\
\text { Finance (SCF) } \\
\text { Ecosystem - Proposing } \\
\text { a Framework and } \\
\text { Agenda for Future } \\
\text { Research }\end{array}$ & $\begin{array}{l}\text { Systematic } \\
\text { literature review } \\
\text { of } 243 \text { articles }\end{array}$ & $\begin{array}{l}\text { Business } \\
\text { Ecosystem }\end{array}$ & $\begin{array}{l}\text { The article introduces the business } \\
\text { ecosystem concept to the SCF domain. } \\
\text { Based on the presented SCF } \\
\text { framework, an agenda for future SCF } \\
\text { ecosystem research is proposed. }\end{array}$ & $\begin{array}{l}\text { The framework aims to serve as an } \\
\text { overview of SCF to the different } \\
\text { stakeholders, providing guidance } \\
\text { on aspects to consider when } \\
\text { engaging in SCF. The framework } \\
\text { also aims to contribute to the } \\
\text { nascent discussion around the } \\
\text { urgent need for standards in SCF }\end{array}$ \\
\hline $\begin{array}{l}\text { Roberta Pellegrino, } \\
\text { Nicola } \\
\text { Constantino, } \\
\text { Danilo Tauro }\end{array}$ & $\begin{array}{l}\text { Supply Chain Finance: } \\
\text { A Supply Chain } \\
\text { Oriented Perspective to } \\
\text { Mitigate Commodity } \\
\text { Price Risk and } \\
\text { Volatility }\end{array}$ & $\begin{array}{l}\text { Real options } \\
\text { valuation (ROV) } \\
\text { model applied to } \\
\text { real FMCG cases }\end{array}$ & Real Options & $\begin{array}{l}\text { Contributes to the nascent theoretical } \\
\text { debate in SCF literature on the } \\
\text { effectiveness of Supply Chain Risk } \\
\text { Management (SCRM) strategies in } \\
\text { mitigating CPV. }\end{array}$ & $\begin{array}{l}\text { Provides managers with a tool to } \\
\text { evaluate the effectiveness of } \\
\text { adopting the two sourcing } \\
\text { strategies for mitigating CPV } \\
\text { under different conditions and to } \\
\text { choose the most appropriate } \\
\text { mitigation strategy depending on } \\
\text { the context. }\end{array}$ \\
\hline $\begin{array}{l}\text { Steven Carnovale, } \\
\text { Dale Rogers, } \\
\text { Sengun Yeniyurt }\end{array}$ & $\begin{array}{l}\text { Broadening the } \\
\text { Perspective of Supply } \\
\text { Chain Finance: The } \\
\text { Performance Impacts of } \\
\text { Network Power and } \\
\text { Cohesion }\end{array}$ & $\begin{array}{l}\text { Econometric } \\
\text { analysis of a } \\
\text { longitudinal panel } \\
\text { of automotive } \\
\text { dynamic supply } \\
\text { networks }\end{array}$ & $\begin{array}{l}\text { Network Theory, } \\
\text { Resource } \\
\text { Dependency } \\
\text { Theory }\end{array}$ & $\begin{array}{l}\text { This research integrates two theoretical } \\
\text { perspectives, resource dependency } \\
\text { theory and network theory, to } \\
\text { contribute to SCF research from a non- } \\
\text { traditional perspective: the impact that } \\
\text { network structure has on resource } \\
\text { access, and therefore the firm's } \\
\text { financial performance }\end{array}$ & $\begin{array}{l}\text { Procurement professionals need to } \\
\text { be aware of the relationship } \\
\text { between the structure of their } \\
\text { supply chain networks and the } \\
\text { financial performance of their } \\
\text { firm. Managers should consider } \\
\text { the role that their first-degree } \\
\text { supply base connections, and } \\
\text { extended networks, have on their } \\
\text { financial performance. }\end{array}$ \\
\hline $\begin{array}{l}\text { Judith Martin, Erik } \\
\text { Hofmann }\end{array}$ & $\begin{array}{l}\text { Towards a Framework } \\
\text { of Supply Chain } \\
\text { Finance for the Supply } \\
\text { Side }\end{array}$ & $\begin{array}{l}\text { Case studies of } \\
\text { eight buyer- } \\
\text { supplier-financial } \\
\text { service provider } \\
\text { triads }\end{array}$ & $\begin{array}{l}\text { Contingency } \\
\text { Approach, Social } \\
\text { Exchange Theory } \\
\text { (SET), } \\
\text { Transaction Cost } \\
\text { Economics } \\
\text { (TCE), Principal } \\
\text { Agent Theory } \\
\text { (PAT) }\end{array}$ & $\begin{array}{l}\text { The article combines the contingency } \\
\text { approach with SET, TCE and PAT to } \\
\text { derive criteria to select different } \\
\text { practices. Findings also consider } \\
\text { contextual situations permitting the } \\
\text { combination of several practices, } \\
\text { resulting in a differentiated approach, } \\
\text { considering three types of reasons } \\
\text { (financial, cash flow-related, and } \\
\text { relational) explaining supplier's } \\
\text { commitment to SCF. }\end{array}$ & $\begin{array}{l}\text { Buying companies are provided } \\
\text { with an enhanced understanding of } \\
\text { relevant actors and can } \\
\text { consequently develop } \\
\text { individualized approaches for } \\
\text { addressing suppliers. Suppliers can } \\
\text { better understand the financing } \\
\text { alternatives available to them. } \\
\text { Finally, FSPs can utilize the } \\
\text { results to improve their services }\end{array}$ \\
\hline
\end{tabular}




\begin{tabular}{|c|c|c|c|c|c|}
\hline & & & & & $\begin{array}{l}\text { related to inter-organizational } \\
\text { financing. }\end{array}$ \\
\hline $\begin{array}{l}\text { Haitao Li, Liuqing } \\
\text { Mai, Wenlong } \\
\text { Zhang, Xiangyu } \\
\text { Tian }\end{array}$ & $\begin{array}{l}\text { Optimizing the Credit } \\
\text { Term Decisions in } \\
\text { Supply Chain Finance }\end{array}$ & $\begin{array}{l}\text { Stackelberg } \\
\text { bilevel } \\
\text { optimization } \\
\text { model (nonlinear } \\
\text { programming) } \\
\text { applied to a } \\
\text { manufacturing } \\
\text { case }\end{array}$ & Game Theory & $\begin{array}{l}\text { The proposed model addresses } \\
\text { supplier-buyer interaction, prescribing } \\
\text { the dynamic credit term over multiple } \\
\text { time periods, which is suitable for the } \\
\text { complex and flexible real-world } \\
\text { decision environment. }\end{array}$ & $\begin{array}{l}\text { The model assists purchasing and } \\
\text { supply managers to make optimal } \\
\text { dynamic credit term decision in } \\
\text { conjunction with production, } \\
\text { ordering and inventory decisions. } \\
\text { Moreover, the multiperiod } \\
\text { dynamic framework enables } \\
\text { decision-makers to plan and } \\
\text { evaluate both the in-bound and } \\
\text { out-bound cash flows as a result of } \\
\text { the credit term, production, } \\
\text { ordering, and inventory decisions. }\end{array}$ \\
\hline $\begin{array}{l}\text { Matthijs van } \\
\text { Bergen, Michiel } \\
\text { Steeman, Matthew } \\
\text { Reindorp, Luca } \\
\text { Gelsomino }\end{array}$ & $\begin{array}{l}\text { Supply Chain Finance } \\
\text { Schemes in the } \\
\text { Procurement of } \\
\text { Agricultural Products }\end{array}$ & $\begin{array}{l}\text { Analytical model } \\
\text { of a three stage } \\
\text { agri-food supply } \\
\text { chain comparing } \\
\text { three SCF } \\
\text { schemes, applied } \\
\text { to Heineken's } \\
\text { barley-malt } \\
\text { supply chain }\end{array}$ & & $\begin{array}{l}\text { Extends the SCF literature to include } \\
\text { Hard Tolling and Contract Farming } \\
\text { schemes. There is opportunity to realize } \\
\text { win-win situations that are beneficial to } \\
\text { all participants, provided that } \\
\text { agreement can be reached on the } \\
\text { division of benefits. Therefore, contract } \\
\text { design (re)emerges as an opportunity at } \\
\text { the interface of the literature on SCF } \\
\text { and supply chain coordination. }\end{array}$ & $\begin{array}{l}\text { The agricultural industry is under } \\
\text { working capital pressure due to its } \\
\text { long lead times and non-standard } \\
\text { SCF schemes offer innovative } \\
\text { solutions. Results may guide } \\
\text { decisions about adopting Soft } \\
\text { Tolling, Hard Tolling, or Contract } \\
\text { Farming. The preferred SCF } \\
\text { scheme can be inferred on the } \\
\text { basis of relatively simple } \\
\text { characterization of the capital } \\
\text { constraints in the supply chain }\end{array}$ \\
\hline $\begin{array}{l}\text { Luca Gelsomino, } \\
\text { Ronald de Boer, } \\
\text { Michiel Steeman, } \\
\text { and Alessandro } \\
\text { Perego }\end{array}$ & $\begin{array}{l}\text { An Optimisation } \\
\text { Strategy for Concurrent } \\
\text { Supply Chain Finance } \\
\text { Schemes }\end{array}$ & $\begin{array}{l}\text { Optimization } \\
\text { model combining } \\
\text { three SCF } \\
\text { solutions applied } \\
\text { to a real retail } \\
\text { case }\end{array}$ & & $\begin{array}{l}\text { The article contributes to the } \\
\text { quantitative assessment of the benefits } \\
\text { of SCF schemes and addresses the } \\
\text { innovative topic of the concurrent } \\
\text { adoption of multiple SCF schemes. } \\
\text { Results show how key parameters } \\
\text { influence the benefits of the adoption of } \\
\text { multiple SCF schemes. }\end{array}$ & $\begin{array}{l}\text { Practitioners can determine the } \\
\text { optimal allocation of suppliers to } \\
\text { different } \\
\text { SCF schemes, identifying which } \\
\text { SCF scheme is relevant for their } \\
\text { supply chain and taking steps } \\
\text { towards the definition of an SCF } \\
\text { strategy. }\end{array}$ \\
\hline $\begin{array}{l}\text { Antonella Moretto, } \\
\text { Laura Grassi, } \\
\text { Federico Caniato, } \\
\text { Marco Giorgino, } \\
\text { Stefano Ronchi }\end{array}$ & $\begin{array}{l}\text { Supply Chain Finance: } \\
\text { From Traditional to } \\
\text { Supply Chain Credit } \\
\text { Rating }\end{array}$ & $\begin{array}{l}\text { Multiple case } \\
\text { studies and } \\
\text { iterative focus } \\
\text { group involving } \\
\text { suppliers, buyers, } \\
\text { financial } \\
\text { institutions, and }\end{array}$ & $\begin{array}{l}\text { Stakeholder } \\
\text { Theory }\end{array}$ & $\begin{array}{l}\text { The article proposes an innovative } \\
\text { solution to a major limitation of } \\
\text { traditional financial rating, in particular } \\
\text { for SMEs, by combining two well } \\
\text { established but separate streams of } \\
\text { research. It also contributes to the } \\
\text { literature on supply risk management }\end{array}$ & $\begin{array}{l}\text { Results offer practical implications } \\
\text { for the four actors investigated: } \\
\text { buyers can improve their supplier } \\
\text { risk assessment and provide } \\
\text { financial support to strategic } \\
\text { suppliers; suppliers can offer a } \\
\text { more reliable presentation of }\end{array}$ \\
\hline
\end{tabular}




\begin{tabular}{|l|l|l|l|l|}
\hline & $\begin{array}{l}\text { technology } \\
\text { providers }\end{array}$ & & $\begin{array}{l}\text { and applies stakeholder theory to the } \\
\text { SCF domain, considering the } \\
\text { perspectives of the four main actors } \\
\text { involved. }\end{array}$ & $\begin{array}{l}\text { themselves to financial } \\
\text { institutions; financial institutions } \\
\text { can improve the accuracy of their } \\
\text { ratings, in particular for SMEs; } \\
\text { technology providers can develop } \\
\text { their business by offering an } \\
\text { innovative solution. }\end{array}$ \\
\hline
\end{tabular}

